\title{
Impact of oxidative stress on myocardial damage visualized by cardiac resonance imaging in acute ST-elevation myocardial infarction
}

\author{
Georg Fuernau ${ }^{1 *}$, Steffen Desch ${ }^{1,2}$, Suzanne de Waha ${ }^{1,3}$, Gerhard Schuler $^{1}$, Volker Adams ${ }^{1}$, Holger Thiele ${ }^{1,2}$, \\ Ingo Eitel ${ }^{1,2}$
}

From 18th Annual SCMR Scientific Sessions

Nice, France. 4-7 February 2015

\section{Background}

In acute ST-elevation myocardial infarction (STEMI) oxidative stress is an important determinant of severe myocardial damage and reperfusion injury. However, no data are currently available about the correlation of oxidative stress with cardiac magnetic resonance (CMR) markers of myocardial injury in acute STEMI.

\section{Methods}

We studied 198 patients with acute STEMI undergoing primary percutaneous coronary intervention (PCI) within 12 hours of symptom onset. Oxidative stress was determined by oxidated LDL-cholesterol (oxLDL), activated oxygen protein products (AOPP) and lipid hydroperoxides (perOx). Blood samples were collected before PCI, after PCI and on day 2 as well as day 3 and 4. Follow-up values were expressed as ratio to baseline values. CMR studies were performed 2-4 days after the infarction (median 3 days, interquartile range 2, 4 days) using a standard infarction protocol.

\section{Results}

A rise in oxidative stress parameters after reperfusion was found in oxLDL for $50.2 \%$, in AOPP for $38.3 \%$ and in perOx for $55.2 \%$ of all STEMI patients on day 2. There were no significant differences in CMR parameters when comparing patients according to the rise or fall of oxidative stress parameters, except for microvascular obstruction (MO) and AOPP ( $\mathrm{p}=0.043$, Table 1). In multivariable stepwise regression analysis for prediction of MO including AOPP, TIMI flow after PCI, diabetes mellitus, pain to balloon time and TIMI risk Score only diabetes remained a significant predictor (Beta 0.22; $\mathrm{p}=0.004$ ). AOPP values after PCI, on day 3 or 4 after PCI were also no independent predictor of MO.

\section{Conclusions}

Rise or fall of markers of oxidative stress had no relevant impact on CMR markers of myocardial damage in acute STEMI. Further studies are necessary to elucidate

Table 1

\begin{tabular}{|c|c|c|c|c|c|c|c|c|c|}
\hline Day 2 & perOx $\leq 1$ & $\$ 1$ & $p$ & $\mathrm{AOPP} \leq 1$ & $\mathrm{AOH}$ & $p$ & $\mathrm{OxLDL} \leq 1$ & oxLL & $p$ \\
\hline Infarct size $\% \mathrm{LV}$ & $18.7(9.4 ; 26.5)$ & $14.2(8.9 ; 23.0)$ & 0.25 & $16.6(9.3 ; 25.7)$ & $13.5(6.0 ; 26.8)$ & 0.29 & $17.5(9.3 ; 25.9)$ & $16.2(7.3 ; 26.5)$ & 0.59 \\
\hline icrovascular obstruction \%LV & $0.7(0.2 ; 1.2)$ & $0.6(0.2 ; 1.6)$ & 0.95 & $0.8(0.3 ; 1.4)$ & $0.4(0.0 ; 1.6)$ & 0.043 & $0.7(0.3 ; 1.5)$ & $0.6(0.0 ; 1.2)$ & 0.28 \\
\hline sk \%LV & 34.4( & $4 ; 44.1)$ & 0.96 & $7.7 ; 44.5)$ & $7 ; 43.1)$ & 0.48 & $6 ; 43.9)$ & $33.8(28.3 ; 43.1)$ & 0.45 \\
\hline Myocardial salvage index & $45.6(26.0 ; 73.5)$ & $54.1(30.2 ; 73.7)$ & 0.32 & $43.1(26.4 ; 73.3)$ & $58.4(29.5 ; 77.1)$ & 0.15 & $48.5(28.5 ; 71.4)$ & $44.8(27.1 ; 75.7)$ & 0.81 \\
\hline
\end{tabular}

${ }^{1}$ University of Leipzig - Heart Center, Leipzig, Germany

Full list of author information is available at the end of the article 
the exact detrimental effect of oxidative stress on myocardial injury in acute reperfused STEMI.

\section{Funding}

N/A.

\section{Authors' details}

${ }^{1}$ University of Leipzig - Heart Center, Leipzig, Germany. ${ }^{2}$ Department of Internal Medicine/Cardiology/Angiology/Intensive Care Medicine, University Hospital Schleswig-Holstein, Campus Lübeck, Lübeck, Germany. ${ }^{3}$ Heart Center Bad Segeberg, Bad Segeberg, Germany.

Published: 3 February 2015

doi:10.1186/1532-429X-17-S1-P99

Cite this article as: Fuernau et al: Impact of oxidative stress on myocardial damage visualized by cardiac resonance imaging in acute ST-elevation myocardial infarction. Journal of Cardiovascular Magnetic Resonance 2015 17(Suppl 1):P99.

Submit your next manuscript to BioMed Central and take full advantage of:

- Convenient online submission

- Thorough peer review

- No space constraints or color figure charges

- Immediate publication on acceptance

- Inclusion in PubMed, CAS, Scopus and Google Scholar

- Research which is freely available for redistribution

Submit your manuscript at www.biomedcentral.com/submit 